\title{
Skeletal Organization of Caudal Fin in Syngnathus abaster (Osteichthyes, Syngnathidae)
}

\author{
Organización Esqueletal de la Paleta Caudal en Syngnathus abaster (Osteichthyes, Syngnathidae)
}

\author{
Valerio Bartolino
}

BARTOLINO, V. Skeletal organization of caudal fin in Syngnathus abaster (Osteichthyes, Syngnathidae). Int. J. Morphol., 23(4):305308, 2005.

SUMMARY: The caudal skeleton is one of the most important tools to evaluate teleostean interrelationships, but just the anatomy of few species have been investigated. Black-striped pipefish (Syngnathus abaster) has never been examined for its caudal morphology. Here, red alizaryn is applied as specific staining for calcified structures, providing a better understanding of caudal skeleton organization. Our results and interpretation just partially fit with previous knowledge on other Syngnathus species. This emphasizes both the importance of facing same problems with new technics and methodologies, and the existence of a heterogeneous situation between close-related taxa.

KEY WORDS: Caudal skeleton; Syngnathus; Teleosts; Red alizaryn.

\section{INTRODUCTION}

The evolution of the caudal fin has become such an important tool in systematics that "nearly every investigator who has discussed the evolution of vertebrates has commented on the caudal fin of ray-finned fishes (Actinopterygii)" (Lauder, 1989).

The caudal skeleton is a major character complex used in the evaluation of teleostean interrelationships. In a large number of cases, the development of various structures of the caudal skeleton corroborates interrelationships based on adult structures (Mehta et al., 1989; Schultze \& Arratia, 1989). The Haeckelian recapitulation theory or biogenetic law, which has been discredited in its absolute form, finds quite impressive correspondence in caudal fin evolution.

Only few taxa have been investigated about the skeleton anatomy of caudal fin and new results and improvements are expected by the examination of other teleost species (Schultze \& Arratia).

In modern teleosts, a reduction of many skeletal elements of the caudal fin can be observed. This progressive simplification has independently interested several lineages at different taxonomic levels, through fusion and lost of parts (Gosline, 1961) and a today interpretation could represent an interesting but not easy task.
Exterior caudal fin shape is related to different ways of swimming and to ecological features of species (Norman, 1963), but only anatomical studies of skeleton can give systematic and phylogenetic information.

Caudal skeleton of Syngnathus abaster has never been investigated and few observations have interested other specie of the same genus. Although their close systematic position, we expect to find morphological differences in this small pipefish, and thanks to improved staining technic, a better understanding of internal caudal anatomy.

\section{MATERIAL AND METHOD}

Alizaryn and alcian-blu staining (Dingerkus \& Uhler, 1977; Park \& Kim, 1984) is a very useful method for in toto staining of skeletal and cartilagineous tissues. This is why it has found large application in embryology and small size vertebrates research, while the same kind of observations on large organisms need X-rays radiography.

Three adult and one juvenil specimens of $S$. abaster were fixed in $28 \% \mathrm{NaH}_{2} \mathrm{PO}_{4}$ buffered formaldehyde (10\%) and these fixed samples were kept in dark for better 
preserving before staining. After a dehydration with increasing alcohol concentrations, samples were treated with a solution $10 \mathrm{mg}$ of alcian blue $8 \mathrm{GX}$, $80 \mathrm{ml}$ alcohol $95 \%$ and $20 \mathrm{ml}$ glacial acetic acid. Then they were re-hydrated with decreasing alcohol concentrations and passed through an enzymatic solution with $30 \mathrm{ml}$ of a sature $\mathrm{NaBO}_{4}$ solution, 70 $\mathrm{ml}$ distilled water and 1-4 g purified 4xpancreatic trypsine. $0,02-3 \% \mathrm{H}_{2} \mathrm{O}_{2}$ has been used to eliminate chromatophores. Staining with a solution $0,5 \% \mathrm{KOH}$ and 0,03-0,04 $\mathrm{g}$ of red Alyzarin-S. Clarifing with glycerol for an easier observation of skeletrical structures (Park \& Kim; Taylor \& Van Dyke, 1985). Anatomical terminology used is according to Schultze \& Arratia and Matsuoka (1987).

External bony plates that cover pipefishes' body are fully stained in consequence of their strong calcification. A dissection of the last eight caudal segments has removed external bony plates for a clear observation of underneath structures.

\section{RESULTS}

In the caudal skeletal system (Fig. 1) there are a superior and an inferior hypurals $(\mathrm{H})$. Hypural diastema well separates them, defining the upper and lower lobes of the caudal fin. Hypurals are short and large in shape offering a wide surface for the attachment of caudal rays. 5 rays are connected to the superior hypural and 5 to the inferior; this provides a symmetric no specialized homocercal tail with 10 rays. Lepidotrica are unbranched and only in adults segmented. Epurals and uroneurals are lacking.

Preural centrum (PU1) is well distinguished with its ventral parhypural (PH) and dorsal neural arch (NAPU1). Parhypural is separated from hypurals, but anchylosed with the inferior one, and it doesn't support any caudal ray. Dorsal view shows that PU1 has two lateral processes (Fig. 2). No ural centra are present in $S$. abaster. The following vertebral centrum has two well distinguished lateral processes on each side, but only one hemal spine (Fig. 2).

Like most vertebrae of Syngnathus column, preural centra have dorsal neural arches with a complex morphology. They extend along the whole length of centra, but their massive form is lightened by many lateral openings on both sides.
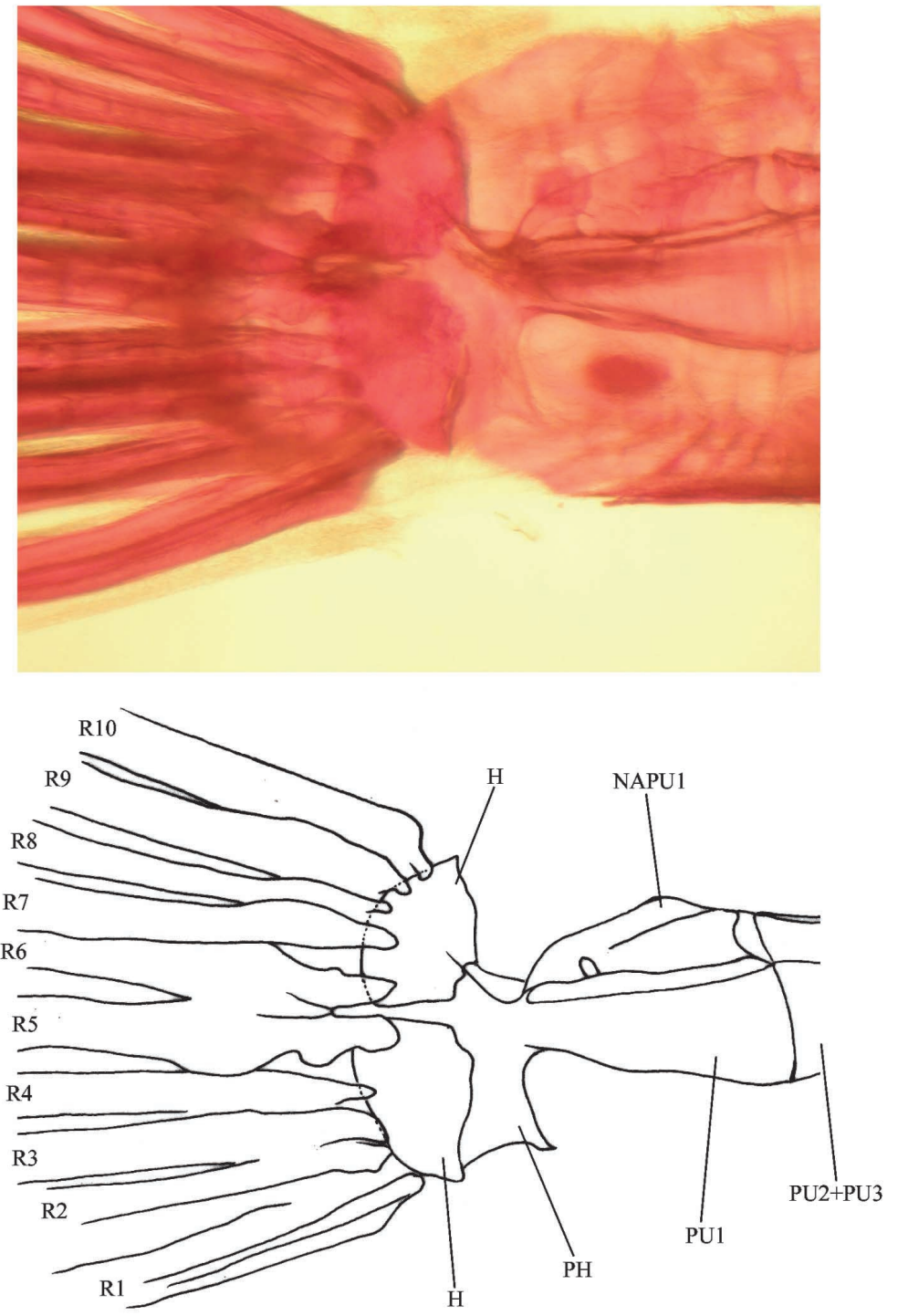

Fig. 1. Caudal skeleton of adult Syngnathus abaster in lateral view, picture and light camera drawing. Abbreviations: hypural $(\mathrm{H})$; parhypural $(\mathrm{PH})$; preural centrum (PU); preural neural arch (NAPU); ray (R).

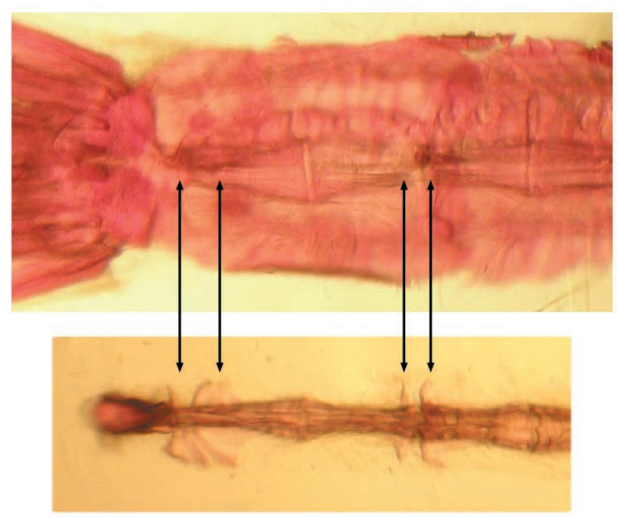

Fig. 2. Caudal skeleton of adult S. abaster in lateral and dorsal view. 


\section{DISCUSSION}

Inferior hypural is probably the result of fusion of the first two hypurals (H1 and $\mathrm{H} 2$ ). About the superior hypural we don't know if it develops from only $\mathrm{H} 3$ or it represents the fusion of more elements. We exclude Hoedeman's interpretation (1961) of this superior hypural as the back portion, or posterior hemiconus, of the last vertebral centrum. This is not only in consequence of their common shape, mostly related to their same function, but also because of their common intesity to the staining reaction.

In many teleosts caudal rays are attached also to the parhypural (PH) and to the hemal spine of the preural 2 (PU2). In S. abaster caudal rays are joined to hypurals like in anguilliform fishes and in that species with a narrow tail fin (Schultze \& Arratia).

Dorsal elements associated with ural centra, epurals and uroneurals, that are present in most of teleosts, are lacking in pipefishes. The presence of uroneurals is considered to be a distinctive feature of the Teleostei (Patterson, 1968; Lauder \& Liem, 1983), but a progressive decrease of these structures has been observed from Jurassic to Recent teleosts (Patterson). They have been lost independently in Syngnathus like in Scarus, Gobius, Merluccius and other acanthopterygians (Monod, 1968).
It is widely accepted that homocercal tail of Teleost is formed by two ural centra. They are the ontogenetic and phylogenetic result of fusion of several vertebral centra that can be still distinguished in most primitive teleosts and in their ancestors. This is often demonstrated by a higher number of hypurals than vertebral centra (Gosline, 1971; Schultze \& Arratia and Nybelin, 1973).

In many teleosts the two ural vertebrae reduce to one and sometimes are fused both with preural 1 (Schultze \& Arratia) like it has happened in S. abaster in which no ural centra are present.

Monod proposed the fusion of preural centra 2 and 3 (PU2 + PU3) in another species of the same genus, Syngnathus acus, on the evidence of two hemal arches under the same vertebral centrum. In S. abaster only one hemal arch can be distinguished and lateral processes are doubled. The evolutionary process of reduction and fusion of preural vertebrae is common to both species and presumably to the genus Syngnathus, but different residual elements are left.

Acknowledgments: I would like to thanks the Laboratory of Experimental Ecology and Aquaculture of the University "Tor Vergata" in Rome, that hosted me during experimental phases of this work.

BARTOLINO, V. Organización esqueletal de la paleta caudal en Syngnathus abaster (Osteichthyes, Syngnathidae). Int. J. Morphol., 23(4):305-308, 2005.

RESUMEN: El esqueleto caudal es una de las más importantes herramientas para evaluar las interrelaciones de teleósteros, pero la anatomía de pocas especies han sido investigada. Nunca se ha estudiado la morfología de la cauda del pez aguja de río de rayas negras (Syngnathus abaster). Se usó una técnica específica de tinción con alizarina roja, para visualizar estructuras calcificadas, obteniéndose un gran conocimiento de la organización del esqueleto caudal. Los resultados e interpretación de ellos coinciden parcialmente con los hallazgos en otras especies de Syngnathus. En ambos casos se enfatiza la importancia de tratar los problemas con nuevas técnicas y metodologías.

PALABRAS CLAVE: Esqueleto caudal; Syngnathus; Teleóstero; Alizarina roja.

\section{REFERENCES}

Dingerkus, G. \& Uhler, L. D. Enzyme clearing of Alcian blu stained whole small vertebrates, for demostration of cartilage. Stain Techn., 5(4):229-32, 1977.

Gosline, W. A. The Perciform caudal skeleton. Copeia, 3: 265-70, 1961.

Gosline, W. A. Functional morphology and classification of Teleostean fishes. Honolulu, University of Hawaii Press, 1971.
Hoedeman, J. J. Contributions to the Osteology of Teleostean Fishes. 1. The caudal skeleton and the hypural complex. Bull. Aquat. Biol., 3(25):17-52, 1961.

Lauder, G. Caudal fin locomotion in ray-finned fishes: historical and functional analyses. Am. Zool., 29:85-102, 1989.

Lauder, G. \& Liem, K. F. The evolution and interrelationships of the Actinopterygian fishes. Bull. Mus. Comp. Zool., Harvard University, 150:95-197, 1983. 
Matsuoka, M. Development of Skeletal Tissues and Skeletal Muscles in the red sea bream, Pagrus major. Bul. Seikai Reg. Fish. Res. Lab., 65, 1987.

Mehta, R.; Devi, K. \& Mehta, H. S. Caudal skeleton in some gobiid fishes and its value in systematics. Res. Bull. Panjab Univ., 40(1-2):29-34, 1989.

Monod, T. Le Complexe urophore des poissons téléostéens. Mem. Inst. Fondamental d'Afrique Noire, 81, 1968.

Norman, J. R. A history of fishes. 2. Ed. London, Ernest Benn Limited, 1963.

Nybelin, O. Comments on the caudal skeleton of actinopterygians. Zool. J. Linn. Soc., 53(Suppl. 1): 369$72,1973$.

Park, E. \& Kim, D. A procedure for staining cartilage and bone of whole vertebrate larvae while rendering all other tissues trasparent. Stain Techn., 59(5): 269-72, 1984.

Patterson, C. The caudal skeleton in Lower Liassic pholidophorid fishes. Bull. British Mus. (Natural History), Geology, 16: 201-39, 1968.

Schultze, H. \& Arratia, G. The composition of the caudal skeleton of teleosts (Actinopterygii: Osteichthyes). Zool. J. Linn. Soc., 97:189-231, 1989.

Taylor, W. R. \& Van Dyke, G. C. Revised procedures for staining and clearing small fishes and other vertebrates for bone and cartilage study. Cybium, 9(2):107-19, 1985.

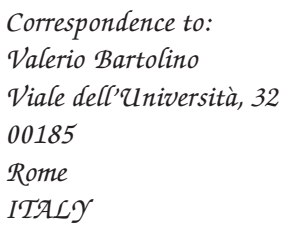

phone/fax: +390649914138

e-mail: valeriobartolino@hotmail.com

Received: 08-07-2005

Accepted: 29-09-2005 